\title{
Suuret museokoneet - fyysisyyttä, historiaa ja kulttuuriperintötyötä
}

Teollinen maailma on täynnä monen kokoisia koneita. Ihminen on tuottanut mitä mielikuvituksellisempia työtä tekeviä laitteita alati kiihtyvällä tahdilla työn muuttuessa ja automatisoituessa. Koneet ovat olennainen osa yhteiskuntaa ja kulttuuriperintöä. Museot ovat täynnä kirjoituskoneita, radioita ja muita arjen välineitä. Suurikokoiset koneet ovat sitä vastoin varsin vaikeita museoesineitä. Suurimmat huoleni merivartiomuseon tutkijana vuosina 2010-2013 liittyivät kokoelman suurimpiin yksilöihin, vartiolaivoihin ja -veneisiin, jotka eivät mahtuneet sisään museon tarkoin valvottuihin ja hallittuihin olosuhteisiin. Työurani järkyttävin tapaus, rannikkovartiolaiva Telkän haveri marraskuussa 2010 muodostui käänteeksi, johon nyt sijoitan sekä laivanrakennusteollisuuden historiaa käsitelleen väitöskirjani idun että tämän teemanumeron synnyn.

Miten voimme tallentaa suuria koneita osaksi teknologisen aikamme kulttuuriperintöä? Mitä nämä koneet kertovat menneisyydestä ja sen säilyttäjistä? Milloin ja miksi tällaiseen koneeseen kannattaa kajota konservointi- tai restaurointitarkoituksella, ja mitä tällöin tulisi ottaa huomioon? Näitä kysymyksiä tämä Teknïkan Waiheita -lehden teemanumero avaa osallistuen täten museoalalla vuosia jatkuneeseen kansainväliseen keskusteluun kookkaiden koneiden museoinnista. Koska tämä keskustelu on toistaiseksi jäänyt teknologian historian tutkijoilta ja harrastajilta suurelta osin piiloon - suuresta yleisöstä ja tiedotusvälineistä puhumattakaan - on koneiden eteen museoissa tehtyä tutkimus- ja kokoelmatyötä tarpeen esitellä yksityiskohtaisesti.

Suuret koneet ovat elimellinen osa elämiämme, mutta vain harvat niistä päätyvät talteen ja säilyvät muistin ankkureina teknologian historian menneiltä vuosikymmeniltä. Mitä suurempi kone on, sitä vaikeampaa sen tallentaminen ja säilyttäminen on. Sosiaalisen median kampanjat tämän tai tuon asian suojelemiseksi kalpenevat sen valtavan työmäärän rinnalla, joka yhdenkin laivan, junan tai nosturin tallentamisen eteen on yleensä tehtävä. Siksi tämä teemanumero toimii teknologiaa tallentavan museotyön juhlakirjana.

Numeron ideana oli kerätä ideoita ja kokemuksia siitä, miten suuria, mielellään jopa toimintakuntoisia, museokoneita tallennetaan, tutkitaan ja esitellään yleisölle. Suurten koneiden tallentamiseen ja esittämiseen liittyy paljon haasteita, joilla on vaikutusta paitsi kulttuuriperinnön säilyttämisen painotuksiin myös siihen, miten museokävijät nämä kokoelmien helmet kohtaavat. Tämä ongelma on tunnistettu museokentällä jo pitkään, mistä hyvä esimerkki on kokoelmatyön arjesta syntynyt Kookkaat koneet -seminaarisarja Suomessa. Aihetta on käsitelty alan konferensseissa, sillä ongelmat ovat samanlaisia maasta ja museosta riippumatta.

Numeron avaavassa artikkelissa "Innovation in preservation" Rotterdamin Erasmusyliopiston väitöskirjatutkija ja museotoimija Richard Velthuizen esittelee yhden maailman suurimman sataman kehityksen kiehtovaa historiaa avaavan työkoneen, kelluvan pneumaattisen viljaimurin Stadsgraanzuiger 19:n. Ainoa säilynyt, toimintakuntoinen höyryimuri kuvastaa satamatyön teknologisoitumista 1900-luvulla. Valtava kelluva kone on kuitenkin säiden armoilla Rotterdamin merimuseon museoaluslaiturissa, minkä takia sen ylläpitäminen ja käyttö on vaatinut luovia museoratkaisuja. Imuria ylläpitää joukko vapaaehtoisia, joille vanhojen höyrykoneiden käytön hiljainen tieto on tuttua. Kuten monessa muussakin museossa on näiden asiantuntijoiden hiljaisen tiedon siirtäminen osoittautunut vaikeaksi teh- 
täväksi, jos uusia osaajia edes saadaan värvättyä. Velthuizen osoittaa artikkelissaan myös, miten museot joutuvat rakentamaan monimutkaisia, jopa ylirajaisia tukiverkostoja kalliiden ja vaativien koneiden pitämiseksi kunnossa.

Toisessa artikkelissa "'This Thing Still Works, Right?' Interpreting a Stationary Steam Locomotive" Turun yliopiston väitöskirjatutkija Anni Shepherd paneutuu suuren museokoneen käyttökuntoisena pitämisen ja esittämisen ongelmaan Stirling Single N:o 1 -veturin kautta. Iso-Britannian kansallisen rautatiemuseon (National Railway Museum) kokoelmiin kuuluva, kuuluisa veturi osoittaa ne vaikeudet, joita tällaisten suurten museokoneiden esittämisessä usein kohdataan. Moni nykypäivään asti säilynyt kone on hyvin hauras, minkä takia niiden pitäminen toimintakunnossa edellyttää yhä suurempia ja suurempia muutostöitä, osien vaihtamista uusiin, sekä monenlaista kajoamista esineeseen. Tällöin joudutaan miettimään esineen autenttisuutta. Onko siis parempi hyväksyä ajan hampaan vaikutukset ja luopua pitämästä konetta toimintakunnossa vai menetetäänkö silloin jotain olennaista? Shepherd purkaa näitä kysymyksï junahistorian ja -harrastuksen kävijöiden kokemusta vasten.

Kolmas artikkeli, Teppo Moilasen "Moottoriajoneuvot museoajoneuvoina ja museoobjekteina" käsittelee TVH:n 1940-luvun kaluston historian ja Mobilian ajoneuvokokoelman avulla ajoneuvojen kulttuuriperintöarvon määrittämiseen liittyviä ongelmia. Moilanen palauttaa museotyön arkistotutkimuksen haasteisiin ja avaa kansallisesti merkittävän ajoneuvokokoelman edustavuuteen liittyviä piirteitä. Lopuksi hän pohtii museo- ja perinneajoneuvojen historiallista merkitystä. Artikkeli avaa keskustelua autoista museoissa teemanumeron ensimmäisen pitkän katsauksen kanssa.

Katsausartikkelissa "Suuri ilo, kalvava huoli" tieliikenteen valtakunnallisen erikoismuseo Mobilian huolto- ja kunnostamisprojekteista vastaava projektipäällikkö Anni Antila purkaa tyhjentävästi museokoneisiin liittyviä museaalisia kysymyksiä teoriaa ja käytäntöä yhdistellen. Katsaus kontekstualisoi numeron vertaisarvioituja artikkeleita suomalaisen ammatillisen museotyön periaatteita vasten ja jäsentää koneiden tallentamiseen ja säilyttämiseen liittyviä ongelmia kolmen eri museoissa säilytettävän museokulkuneuvon avulla. TVH:n Koli-Vanaja (Mobilia), puolustusvoimien KrAZ-255b (Museo Militaria) ja Riihimäen kauppalan Fordson Sussex (Riihimäen kaupunginmuseo) ilmentävät autohistorian tallentamisen monia haasteita mutta myös niitä oivaltavia ratkaisuja, joihin museoammattilaiset ovat vuosien saatossa päätyneet.

Suomen merimuseon museolehtori Johanna Aartomaan ja vene- ja laivamestari Juha Puustisen lyhyt katsaus "Voimaa ja valoa Suomen merimuseon museolaivoista" esittelee museon suurten alusten, jäänmurtaja Tarmon ja majakkalaiva Kemin (molemmat yli satavuotiaita) kunnostustelakointeja ja niiden osana tehtyä tutkimus- ja kokoelmatyötä. Kuten tämän numeron artikkeleista on käynyt ilmi, ei suuren koneen ylläpito onnistu ilman tutkimustyötä. Usein tämä vaivannäkö vaan jää piiloon museoiden kirjastoihin toisin kuin akateemisissa julkaisuissa tehty tutkimus. Esinetutkimuksen merkitys historiantulkinnoille ja teknologian historian materiaalisuuden ymmärrykselle on silti valtava.

Numerossa julkaistaan myös Veijo Kauppisen lyhyt artikkeli "Ilmarinen - Viron presidentin ja ylipäällikön konepaja". Kauppinen nostaa esiin paitsi konepajahistorian myös Viron historian osalta kiinnostavan teollisuuslaitoksen vaiheita. Suomen lähialueiden teollisuushistoria johtaa pohtimaan oman konepajahistoriamme ydinkysymyksiä ja luonnetta. 
Numeron päättävät Kimi Kärjen (Adrienne Mayor: Gods and robots) ja Aaro Saharin (Larrie D. Ferreiro: Bridging the seas.) kirja-arvostelut.

Museoihin tallennetut suuret koneet ovat osa teknologian historiaa ja teollistuneen sekä verkostoituneen Suomen tarinaa. Nämä koneet vaativat kuitenkin erityisiä, usein poikkeuksellisia toimenpiteitä mutta myös valtavan määrän arkista museotyötä säilyäkseen tuleville sukupolville. Kuten tämän numeron artikkelit oivallisesti osoittavat, ne vaativat myös pyyteetöntä ja tarkkaa tutkimusta, historian selvittämistä ja tulkitsemista arkistoissa, materiaalien ja työmetodien selvittämistä, esitystapojen ja museopedagogian oivaltavia ratkaisuja, sekä verkostotyötä käyttäjäorganisaatioiden, yhteisöjen ja tekniikan historian harrastajien sitomiseksi vaativien museoesineiden tulevaisuuden takaamiseksi. Toivottavasti tähän kerätyt kirjoitukset inspiroivat jatkamaan työtä näiden historiamme koneiden säilyttämiseksi ja esittämiseksi. Kiitos vaivannäöstä kuuluu artikkelien kirjoittajille ja niille lukuisille museoammattilaisille, joiden viisaiden sanojen tuloksena tämä numero syntyi.

Hyvää alkanutta vuotta ja antoisia lukuhetkiä!

\section{Aaro Sahari}

Toimitusneuvoston jäsen

Tekniikan Waiheita

To cite this article: Aaro Sahari, "Suuret museokoneet - fyysisyyttä, historiaa ja kulttuuriperintötyötä" Tekniikan Waiheita 39, no. 1(2021): 4-6. https://doi.org/10.33355/tw.103100

To link to this article: https://dx.doi.org/10.33355/tw.103100 